人工肛門設着鶏の術後経過に伴う飲水量および排泄水分量の変化

\author{
一色泰・中広義雄 \\ 香川大学農学部・香川県 761-07
}

著者ら はさきに, 鶏の直腸を各部位で切断して人工 肛門を設着し，1か月後に扮ける水分出納を測定した。 その結果, 切断部位のいかんにかかわらず対照鶏に比し て飲水量が 70-80\%有意に增加することを認めた。また
DICKER と $\mathrm{HASLAM}^{2)}$ も，輸尿管分離手術を施した鷄に㧤 いて同様な現象を認めている。しかし人工肛門を設着し た鶏に扣いて，水分撰取量が増大する原因についてはな お不明の点が多い。

表 1. 人工肛門設着が水分拱取量および水分排泄 Table 1. Effect of colostomy on water intake and

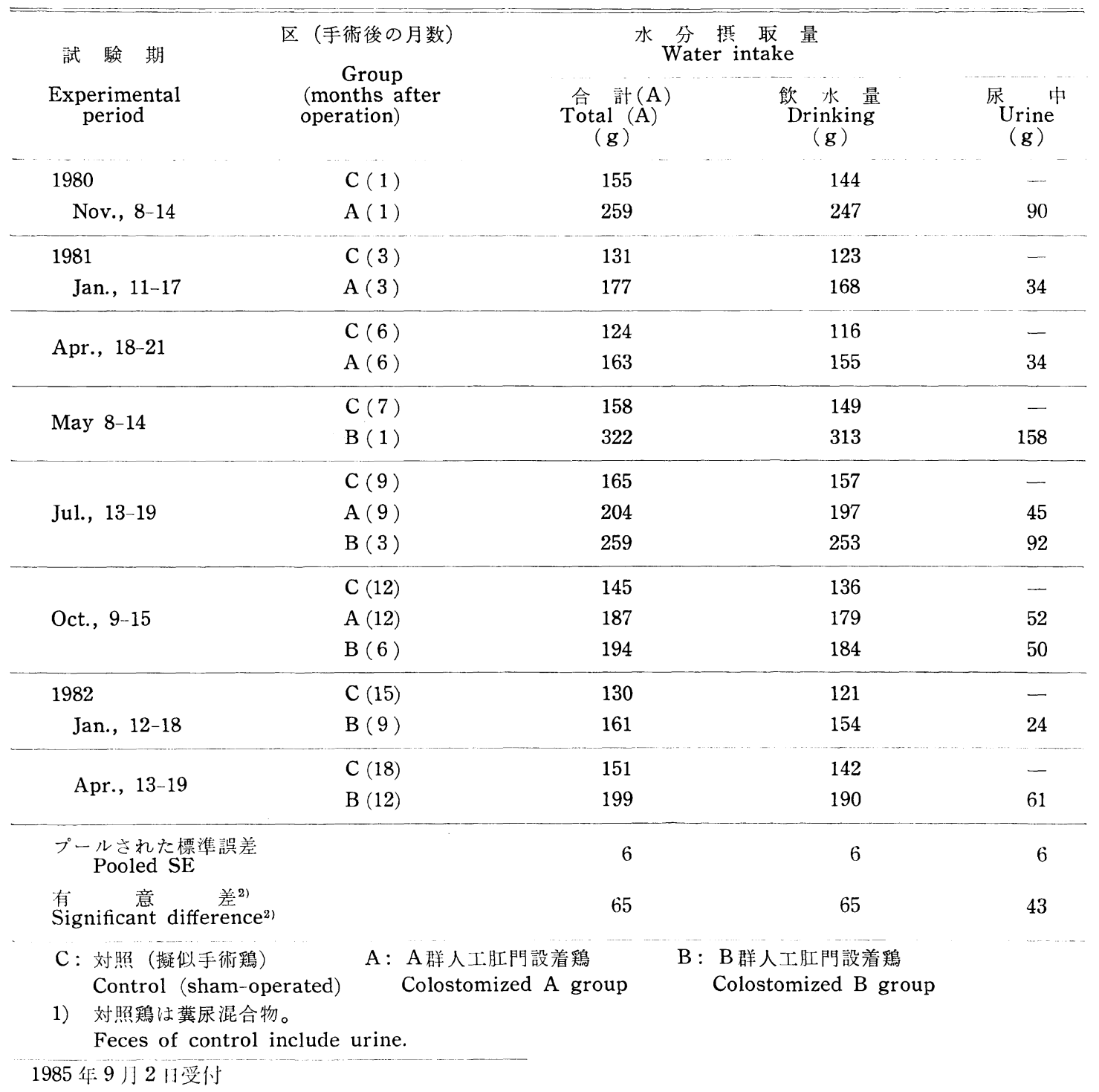


本研究は, 人工肛門設着鷄について手術後 1 か月より 12 か月まで 経時的に水分出納を測定し, 鶏の水分代謝機 構に関する手がかりを得ようとしたものである。

\section{材料および方法}

通常の方法で飼育した 6 か月齢の単冠白色レグホーン 雄 15 羽を 5 羽ずつの 3 群に分け, 万ち 1 群（人工肛門 $\mathrm{A}$ 群) には直ちに（1980 年 10 月）人工肛門設着手術を行 い, 他の 1 群には擬似手術を施して対照群とした。残り の 1 群はそのままさらに 6 か月間継続飼育して, 翌年 4 月に人工肛門を設着した (人工肛門 B 群)。人工肘門設着 法およびその後のカニューレ挿入と管理は前報3)に示し
た通りである。

試験は表 1 に示したごとく, A, B 両群とも手術後 1 , 3，6，9および 12 か月にそれぞれ 7 日間（予備期 3 日， 試験期 4 日）行ったが，擬似手術鵎は全期間にわたり同 一鶏を用いたので，B群とは術後の経過月数が異なって いた。供試鶏は個体別ケージに収容し, 黄色とうもろこ

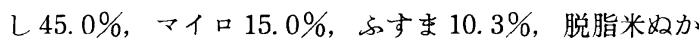
$15.0 \%$, 大豆かす $5.0 \%$, 魚粉 3.0\%, アルファルファ・ ミール $4.0 \%$, 炭酸カルシウム $1.3 \%$, 第 3 燐酸カルシウ ム $0.7 \%$, 食塩 $0.4 \%$ ， ミネラル混合物 ${ }^{1)} 0.05 \%$ および ビタ ミン混合物 ${ }^{1)} 0.25 \%$ より成る CP 14.9\%, ME 2.55 $\mathrm{kcal} / \mathrm{g}$ (計算值 $\left.{ }^{4}\right)$ ) の配合飼料を水とともに自由掑取さ

量に及ぼす影響（ 5 羽による平均值/日）

water excretion in birds (Mean for 5 birds/day)

\begin{tabular}{|c|c|c|c|c|c|c|}
\hline \multirow{2}{*}{$\begin{array}{l}\text { Wat } \\
\text { W } \\
\text { Feces } \\
\text { (g) }\end{array}$} & \multirow{2}{*}{$\begin{array}{c}\begin{array}{c}\text { 排 泄 量 } \\
\text { excretion }\end{array} \\
\text { 合 部 (B) } \\
\begin{array}{c}\text { Total (B) } \\
(\mathrm{g})\end{array}\end{array}$} & \multirow[b]{2}{*}{$\begin{array}{c}\text { 水分排泄率 }(\mathrm{B} / \mathrm{A})(\%) \\
\text { Percent of } \\
\text { total intake }\end{array}$} & \multicolumn{2}{|c|}{ Feces } & \multicolumn{2}{|c|}{$\begin{array}{c}\text { 尿 } \\
\text { Urine }\end{array}$} \\
\hline & & & $\begin{array}{c}\text { 排泄量 } \\
\text { Quantity } \\
(\mathrm{g})\end{array}$ & $\begin{array}{c}\text { 水分含量 } \\
\text { Water } \\
(\%)\end{array}$ & $\begin{array}{l}\text { 排 泄 量 } \\
\text { Quantity } \\
\qquad(\mathrm{g})\end{array}$ & $\begin{array}{c}\text { 水分含量 } \\
\text { Water } \\
(\%)\end{array}$ \\
\hline - & 101 & 65 & 127 & 79.6 & - & $\ldots$ \\
\hline 92 & 182 & 70 & 114 & 80.6 & 96 & 94.1 \\
\hline- & 70 & 53 & 92 & 76.4 & - & - \\
\hline 71 & 105 & 59 & 89 & 79.4 & 38 & 89.2 \\
\hline- & 64 & 51 & 86 & 74.1 & - & - \\
\hline 62 & 96 & 59 & 78 & 79. 6 & 39 & 87.5 \\
\hline- & 99 & 63 & 125 & 78.8 & - & - \\
\hline 88 & 246 & 76 & 110 & 80.6 & 162 & 97.0 \\
\hline- & 70 & 43 & 88 & 79.4 & - & - \\
\hline 57 & 102 & 49 & 70 & 81.3 & 52 & 86.5 \\
\hline 58 & 150 & 58 & 73 & 80.4 & 97 & 94.5 \\
\hline- & 80 & 55 & 106 & 75.2 & - & - \\
\hline 63 & 116 & 61 & 80 & 78.9 & 58 & 89.7 \\
\hline 74 & 124 & 64 & 92 & 79.7 & 56 & 90.5 \\
\hline- & 68 & 52 & 90 & 75.3 & - & - \\
\hline 68 & 92 & 58 & 86 & 78.8 & 29 & 82.9 \\
\hline- & 83 & 55 & 104 & 79.6 & - & - \\
\hline 65 & 126 & 63 & 82 & 79.3 & 66 & 90.8 \\
\hline 2 & 5 & 1 & 3 & 0.3 & 6 & 0.7 \\
\hline 26 & 44 & 12 & 37 & 4.7 & 43 & 6.3 \\
\hline
\end{tabular}

2) スチューデント化された範囲 $Q$ による $(P=0.05) 。$ Based on Studentized range $\mathrm{Q}(\mathrm{P}=0.05)$. 
せた。

4 日間の試験期間には，飲水量を測定するとともに排 泄物を全量採取した。飲水量の調査は, $300 \mathrm{ml}$ ポリエチ レン製ビーカーに $250 \mathrm{ml}$ の水を容れて毎日 6 時と 12 時 に設置し，それぞれ 12 時および 19 時に残量を計量した が，その際別に設置した飲水器よりの蒸散量を測定し， これで補正して正味の飲水量を求めた。粪は人工肛門に 取り付けた筒状ビニールカバー中のポリエチレン製ビー カーに，また尿は ARIYOSHI と MORIMOTO5) による採尿 管を用いて，これに装着した二重ビニール袋に採取し た。䔬および尿の採取は 7 時, 13 時および 20 時の 3 回 行った。

水分摂取量は飲水量と飼料中の水分量を合計して求 め, 粪および尿は採取後值ちに水分含量を測定した。な お飼料摂取量は，あらかじめ飼料中に混入した酸化ク口 ムの糞中への排泄量から逆算して求めた。酸化ク口ムは 霬中にほぼ完全に排泄される6) とされているので, 酸化 クロムの回収率を $100 \%$ として計算した。なお酸化クロ ムの定量は BOLIN ら の)方法によった。

\section{結果}

人工肛門設着後経時的に調べた水分㩒取量および水分 排泄量を表 1 に示した。

人工肛門設着鷄と対照鷄の体重および飼料摂取量は特 に示さなかったが, 各期とも群間に有意差を認めなかっ た。人工肛門設着鵎の飲水量は, 両群とも手術後 1 か月 では対照舀に比して非常に多く，A 群では対照鶏の 1.7 倍, B群では 2 倍にも増加した。その後増加率は減少し
たが，手術後 3 か月で $\mathrm{A}$ 群は 1.4 倍， B 群は 1.6 倍を示 し, 手術後 6 か月以降ではいずれも 1.3 倍前後で恒常的 に推移した。摂取した飼料中の水分含量は各群，各期と も大きな変化はなかったので, 搨取総水分は飲水量と平 行的な関係にあった。

人工肛門設着鶏の排䔬量は, $\mathrm{A}, \mathrm{B}$ 両群とも手術後 1 か月で若干高い傾向にあったが，全期間を通じて有意差 はみられなかった。対照䳕では糞尿混合物量で示してあ るが，その量は人工肛門設着鷄の䔬尿の合計量に比して 非常に少なく，むしろその粪量とほぼ一致し，両者の間 に有意な差を示さなかった。手術後 1 か月の排尿量は他 の時期に比して多かったが，これはこの時期に飲水量が 多かったためと考えられ, 飲水量が恒常に達してからは それほど大きな差はみられなかった。な和尿中水分含量 は，飲水量とほぼ同一の傾向を示していた。糞尿中への 水分排泄量は水分摂取量をよく反映し，人工肛門設着鷄 は詨照鷄より排泄量が多かったが，手術後 1 か月ではそ の差が特に大きかった。摂取水分に対する排泄水分の割 合 (排泄率) は, 全体を通じて人工肛門設着鷄の方が対 照䳕に比べ 10-20\%高い傾向を示した。

なお手術後初期の状況を知るために，術後 5-7 日およ び15-17 日に飲水量を測定した結果を表 2 に示した。対 照鵎（擬似手術鵎）は手術の前後を通じて差を認めなか ったが，人工肛門設着鷄では術後の增加が著しかった。

\section{考察}

本実験の結果は，鷄に人工肛門を設着すると飲水量が 増加し，その結果水分排泄量が多くなるとする著者ら ${ }^{1)}$

表 2.人工肛門設着前後における飲水量の变化 ( 5 羽による平均值士標準誤差/日)

Table 2. Changes of drinking water before and after colostomy (Mean \pm SEM for 5 birds/day)

$(\mathrm{m} l)$

\begin{tabular}{|c|c|c|c|}
\hline & 手 術 前 & \multicolumn{2}{|c|}{$\begin{array}{c}\text { 手術後の経過日数 } \\
\text { Days after operation }\end{array}$} \\
\hline & Before operation & $5-7$ & $15-17$ \\
\hline 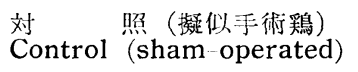 & $153 \pm 9$ & $149 \pm 6$ & $138 \pm 4$ \\
\hline $\begin{array}{l}\text { A 群人工肛門設着鶏 } \\
\text { A group (colostomized) }\end{array}$ & $146 \pm 12$ & $343 \pm 24^{*}$ & $289 \pm 25^{*}$ \\
\hline $\begin{array}{l}\text { 対 } \\
\text { Control 照 (擬似于手術鶏) } \\
\text { (sham-operated) }\end{array}$ & $139 \pm 10$ & $143 \pm 11$ & $148 \pm 13$ \\
\hline $\begin{array}{l}\text { B 群人工肛門設着鶏 } \\
\text { B group (colostomized) }\end{array}$ & $142 \pm 8$ & $365 \pm 28^{* *}$ & $342 \pm 23^{* *}$ \\
\hline
\end{tabular}

*，**対照鷄との間に $5 \%$ および $1 \%$ 水集の住意差あり。 Significantly different from control at $5 \%$ and $1 \%$ level, respectively. 
の報告を再確認したものである。特に，人工肚門設着手 術後 1 か月（ときには 3 か月）で水分の摂取量および排 泄量は著しく高まり，その後減少するものの 1 年を経過 しても通常鷄に比してやや高いレベルを保つことが明ら かになった。人工：月L門設着謟では粪中水分含量が 79 $81 \%$ と比較的一定であったが, 通常慆の総排泄物中水分 含量は74-80\%と変動幅がやや大きかった。これは，通 常鷄の排泄物には尿が混在するので，その影響が大きく 作用するものであろら。しかし尿を含まない人工肛門設 着鵎の䔬中水分含量が，通常鷄の尿を含む総排泄物中水 分含量よりほとんどの例で高くなっていた。著者らは（ 直腸の切断部位を変えて人工肛門を設着しても水分出納 に変化がみられないことを確認しているので，人工肛門 設着鵎の糞中水分含量の多いことは, 直腸の切断に伴ら 吸収面積の減少が主要な要因とは考えられない。

KOIKE ¿ MCFARLAND ${ }^{8)}$ および AKESTER ら ${ }^{9)}$ は, 輸 尿管より排出した尿が腸管内に逆流することを報告して いる。著者ら ${ }^{1)}$, 鵎では盲腸拉よび直腸から尿水分が 吸収されることを認めている。したがって直腸を切断し て人工肛門を設着した鶏では, 尿水分の再吸収が低下し, その結果水分要求量を満たすために水分摂取量が多くな る可能性も考えられる。しかしその量が本実験で得られ たほど大きいものであるかどらかには疑問があろう。

一色10) は，盲腸に分布する血管と神経または神経の みを切断して水分の掑取量と排泄量を調査した。その結 果, 回盲腸動・静脈に附随する神経を切断すると，盲腸 切除の之きと同様に水分の摂取量および排泄量が増大す ることを認め, 盲腸切除による飲水量の増加は飲水中枢 を規制する神経が盲腸切除とともに切断されたためであ ろらと推論した。人工肛門設着手術に際しても，直腸動 ・静脈に附随する神経 ${ }^{11)}$ の切断を伴うので, 盲腸 切除 鶏の場合と同様に飲水量が増加したものと考えられる。

\section{要約}

人工肛門を設着した鷄の飲水量および水分排泄量の経 時的変化を調査するために，6か月齢および 12 か月龊で 人工肘門を設着した単冠白色レグホーン雄を用いて水分
の出納試験を行った。

その結果，人工肛門設着鵎は手術の時期にかかわらず 術後 1 か月では水分摂取量および水分排泄量が通常舀の 2 倍前後にまで増加したが，その後漸減し，6か月以降 では通常鶏より約 $30 \%$ 高いレベルで注ば一定に保たれ ていた。

\section{引用 文 献}

1）中広義雄・一色 泰（1980）鶏大腸に打ける尿中 水分の再吸収について:家禽会誌，17：129-134.

2) Dicker, S. E. and J. Haslam (1972) Effect of exteriorization of the ureters on the water metabolism of the domestic fowl: J. Physiol., 224: $515-520$.

3）中広義雄 (1966) 鶏における飼料の消化率測定法 に関する研究：香川大農学部紀要，22，1-53.

4) 森本 宏 (1977) 飼料学, p. 638-641. 養賢堂, 東京.

5) Ariyoshi, S. and H. Morimoto (1956) Studies on the nitrogen metabolism in the fowl. 1 . Seperation of urine for the nutritional balance studies: Bull. Natl. Inst. Agri. Sci., G 12, $37-$ 43.

6) Müller, W. J. (1956) Feasibility of the chromic oxide and the lignin indicator methods for metabolism experiments with growing chickens: J. Nutr., 61: 29-36.

7) Bolin, D. W., R. P. King and E. W. KlosterMAN (1952) A simplified method for the determination of chromic oxide when used as an index substance: Science, 116: 634-635.

8) Kolke, T. I. and L. Z. McFarland (1966) Urography in the unanaesthetised hydropenic chicken: Am. J. vet. Res.,27: 1130-1133.

9) Akester, A. R., R. S. Anderson, K. J. Hill and G. W. Osbaldiston (1967) A radiographic study of urine in the domestic fowl: Br. Poult. Sic., 8: 209-212.

10）一色 泰 (1980) 鶏盲腸の栄養生理学的研究: 香 川大農学部紀要，36，1-109.

11）渡辺 徹 (1972) 鶏の比較解剖学的並びに局所解 剖学的研究. LXIV. 鶏の交感神経系. その 2 . 腸 神経：日獣医誌，34：303-313. 


\title{
On the Change of Water Balance in the Colostmized Chickens
}

\author{
Yutaka IsSHIKI and Yoshio NAKAHIRO \\ Faculty of Agriculture, Kagawa University, Kagawa-ken 761-07
}

It is well known that the water intake is more in the colostomized chicken than in normal one. In the present experiment with single comb White Leghorn cockerels, water balance was measured to obtain a detailed data in the changes of water intake with the lapse of days after colostomy at the ages of 6 and 12 months.

As a result, water intake and excretion were about to times higher in the colostomized chickens than in normal one at a month after operation, and thereafter, the difference between colostomized and normal birds decreased gradually. At 6 or more months after operation, however, water intake was still about $30 \%$ higher in the colostomized chickens than in normal chickens.

(Japan. Poult. Sci., 23, 18 22, 1986) 